\title{
The Political Aesthetics of Global Protest
}

\author{
The Arab Spring and Beyond \\ Edited by Pnina Werbner, \\ Martin Webb and \\ Kathryn Spellman-Poots
}

\section{EDINBURGH \\ University Press}

IN ASSOCIATION WITH

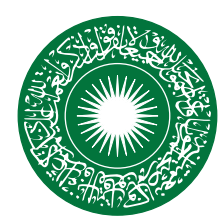

THE AGA KHAN UNIVERSITY

(International) in the United Kingdom

Institute for the Study of Muslim Civilisations 
The opinions expressed in this volume are those of the authors and do not necessarily reflect those of the Aga Khan University, Institute for the Study of Muslim Civilisations.

(C) editorial matter and organisation Pnina Werbner, Martin Webb and Kathryn

Spellman-Poots, 2014

(C) the chapters, their several authors, 2014

First published in hardback in 2014 by

Edinburgh University Press Ltd

The Tun - Holyrood Road

I2 (2f) Jackson's Entry

Edinburgh EH8 8pJ

www.euppublishing.com

Typeset in Goudy Oldstyle by

Koinonia, Manchester and

printed and bound in Spain by Novoprint

A CIP record for this book is available

from the British Library

ISBN $978 \circ 748693344$ (hardback)

ISBN $978 \circ 74869335$ I (paperback)

ISBN 978 o 748693504 (webready PDF)

ISBN 978 o 7486 935 I I (epub)

The right of the contributors to be identified as authors of this work has been asserted in accordance with the Copyright, Designs and Patents Act 1988 and the Copyright and Related Rights Regulations 2003 (SI No. 2498). 